\title{
African locust bean (Parkia biglobosa, Jacq Benth) leaf extract affects mitochondrial redox chemistry and inhibits angiotensin- converting enzyme in vitro
}

Kayode Komolafe ${ }^{1,2,3^{*}}$, Afolabi C. Akinmoladun ${ }^{1}$, Titilope R. Komolafe ${ }^{1}$, Mary T. Olaleye ${ }^{1}$, Akintunde A. Akindahunsi ${ }^{1}$ and Joao B. T. Rocha ${ }^{3}$

\begin{abstract}
Background: Parkia biglobosa leaf has popular ethnomedicinal use in tropical Africa. However, little is known about its molecular biological effects. This study sought to investigate the in vitro antioxidant activity, angiotensin-lconverting enzyme (ACE) inhibition and effects of aqueous-methanolic extract of $P$. biglobosa leaf (PBE) on mitochondrial membrane potential and reactive oxygen species (ROS) generation.

Methods: Antioxidant activity was determined by extract's DPPH. (1,1-diphenyl-2-picrylhydrazyl radical), ABTS $^{+}$[2,2'-azino-bis(3-ethylbenzothiazoline-6-sulfonic acid) diammonium salt radical cation] scavenging ability, reducing property and propensity to inhibit lipid peroxidation induced by prooxidants $\left(\mathrm{FeSO}_{4} / \mathrm{sodium}\right.$ nitroprusside, SNP) in isolated rat tissue preparations. Determination of angiotensin-converting enzyme (ACE) inhibition was based on the hydrolysis of N-hippuryl-His-Leu hydrate $(\mathrm{HHL})$ by the enzyme. Subsequently, the effects of PBE on toxicant-induced mitochondrial ROS formation and basal membrane potential $(\Delta \psi \mathrm{m})$ were determined by 2', 7'-dichlorodihydrofluorescin (DCFH) oxidation and safranine fluorescence respectively.

Results: PBE significantly reduced ferric ions $(P<0.001)$, scavenged $D P P H\left(E C_{50}=98.33 \pm 1.0 \mu \mathrm{g} / \mathrm{mL}\right)$ and ABTS $\left(E C_{50}=45.30 \pm 0.1\right)$ radicals, with moderate $\mathrm{Fe}^{2+}$ - chelating effect $(40 \%)$. In rat liver and brain homogenates respectively, PBE prevented membrane peroxidation induced by $\mathrm{FeSO}_{4}\left(\mathrm{EC}_{50}: 75.87 \pm 2.1 \mathrm{\mu g} / \mathrm{mL}\right.$ and $89.34 \pm 2.5 \mu \mathrm{g} / \mathrm{mL}$ ) and SNP (EC $50: 28.10 \pm 1.6 \mu \mathrm{g} / \mathrm{mL}$ and $17.25 \pm 0.78 \mu \mathrm{g} / \mathrm{mL}$ ). The extract's inhibition of ACE $\left(I C_{50}=51.30 \pm 5.1 \mu \mathrm{g} / \mathrm{mL}\right)$ and mild depolarization of isolated liver mitochondria membrane potential were concentration-dependent. Finally, PBE was more effective than catechin in attenuating calcium and SNP-induced surge in mitochondrial ROS generation.

Conclusion: Parkia biglobosa leaf exhibits considerable ACE inhibitory effect, antioxidant activity and affects mitochondrial redox chemistry. These present findings also justify the ethnobotanical applications of the plant in the indigenous system of medicine.
\end{abstract}

Keywords: Parkia biglobosa, Angiotensin, Antioxidant, Mitochondria, Membrane potential

\footnotetext{
*Correspondence: komokay93@yahoo.com

'Department of Biochemistry, School of Sciences, The Federal University of

Technology, Akure PMB 704, Nigeria

${ }^{2}$ Department of Biochemistry, Faculty of Science, Federal University Oye-Ekiti,

Oye-Ekiti PMB 373, Nigeria

Full list of author information is available at the end of the article
} 


\section{Background}

There is increasing awareness of potential health benefits of naturally occurring phytochemicals from plants. Herbs have long been used for a large range of nutritional and medicinal purposes. In fact, herbs were the basis for nearly all medicinal therapy until synthetic drugs were developed in the nineteenth century [1]. Bioactive molecules from natural sources could have fewer side effects than synthetic ones. The established inverse relationship between intake of plant-derived foods and mortality from age-related degenerative diseases such, as cancer, diabetes, emphysema, cardiovascular diseases and brain dysfunction [2] has been attributed to their antioxidant property. Thus, antioxidant principles from natural sources can provide a multifaceted approach to modulate oxidative imbalance found in human degenerative diseases. Electron leakage from the mitochondrial electron transport chain (ETC) during cellular respiration accounts for about $2 \%$ of oxygen consumed being converted to superoxide anion $\left(\mathrm{O}_{2}^{-}\right)$and this is thought to be the major source of ROS generation in somatic cells [3] with the rate of $\mathrm{O}_{2}^{-}$production being dependent on mitochondrial potential [4]. Mitochondrial ROS production under certain conditions is capable of overwhelming the endogenous antioxidant defence mechanisms, resulting in oxidative stress, with a grave implication in numerous pathological conditions and contributes to retrograde redox signaling from the organelle to the cytosol and nucleus. Early ROS production in the mitochondria could be detected using dichlorodihydrofluorescein (DCFH) derivatives which localize to the mitochondrial matrix [5] and is sensitive to $\mathrm{H}_{2} \mathrm{O}_{2}$ which is immediately generated on spontaneous or catalyzed dismutation of superoxide anion by mitochondrial SOD. The resulting $\mathrm{H}_{2} \mathrm{O}_{2}$ is capable of diffusing out of the mitochondria into the cytoplasm.

Of particular therapeutic significance, polyphenolics appear to play a significant role as antioxidants in the protective effect of medicinal plants [6] and have become the focus of current nutritional and therapeutic interest. Generally, antioxidant compounds like phenolic acids, polyphenols and flavonoids scavenge free radicals such as peroxide, hydroperoxide of lipid hydroxyl and thus inhibit the oxidative mechanisms involved in the progression of degenerative diseases [7]. These natural antioxidants have been shown to have access to metabolic processes and are capable of interrupting free radical-mediated reactions by donating hydrogen from the phenolic hydroxyl groups to free radicals [8]. They also have the aptitude to scavenge oxygen-nitrogen derived free radicals by donating hydrogen atom or an electron, chelating metal catalysts and activating antioxidant enzymes $[8,9]$. Plant phytochemicals have a multifunctional nature. It is, therefore, necessary that in vitro antioxidant investigations combine radical scavenging and lipid peroxidation inhibitory effects in order to arrive at a solid conclusion on the total antioxidant potential of phytochemicals and plant products.

Parkia biglobosa (Jacq.) Benth., commonly known as 'African locust bean', is a plant used extensively in West Africa for timber, food and medicine. It was largely prescribed in traditional medicine for its multiple medicinal virtues in tropical Africa. A decoction of the bark, root and leaves is used in treating toothaches, leprosy, hypertension and fevers [10]. The phenolic constituents [11] and hypotensive effect of the leaf extract was earlier reported [12]. However, the mechanism underlying the hypotensive effect is still a subject of investigation. Also, there is a paucity of information on the antioxidant activity and the effect of the leaf on mitochondrial redox status. In the present study, we have assessed the antioxidant activity, angiotensin-converting enzyme inhibition and effect of the aqueous-methanolic extract of $P$. biglobosa leaf on isolated mitochondrial integrity.

\section{Methods \\ Chemicals}

2,2'-azinobis-(3-ethylbenzothiazoline-6-sulfonic acid) or ABTS and dichlorofluorescin diacetate (DCFHDA) were obtained from Sigma (St. Louis, MO, USA). 6-hydroxy2,5,7,8-tetramethychroman-2-carboxylic acid (Trolox) and 2,2-diphenlyl-1-picrylhydrazyl (DPPH) were obtained from Fluka, Buchs, Switzerland. Potassium persulfate $\left(\mathrm{K}_{2} \mathrm{~S}_{2} \mathrm{O}_{8}\right)$, ethylenediaminetetraacetic acid (EDTA), ascorbic acid, 2- deoxy-2-ribose, trichloroacetic acid (TCA), and quercetin were obtained from Sisco Research Laboratories Pvt. Ltd., Mumbai, India. Hydrogen peroxide, Ferrous sulfate, potassium hexacyanoferrate, Folin-Ciocalteu reagent, sodium carbonate $\left(\mathrm{Na}_{2} \mathrm{CO}_{3}\right)$ and butylated hydroxytoluene (BHT) were obtained from Merck, Mumbai, India. Thiobarbituric acid (TBA) was obtained from Loba Chemie, Mumbai, India.

\section{Plant material}

Fresh leaves of Parkia biglobosa were collected in IsuaAkoko, Ondo State, Nigeria. Botanical identification and authentication was carried out by Dr. Ugbogu A.O and Mr. Shasanya O.S at the herbarium of the Forestry Research Institute (FRIN) Ibadan, Oyo state, Nigeria where a voucher specimen (no 109603) was deposited.

\section{Parkia biglobosa Extract (PBE) preparation}

The leaves were air-dried for 28 days at room temperature and ground to fine powder using a blender. A $500 \mathrm{~g}$ sample of the powdered material was macerated in $1200 \mathrm{~mL}$ of a mixture of methanol and water (4:1) for $48 \mathrm{~h}$. This was filtered and concentrated to a small volume to remove the entire methanol using rotary 
evaporator. The concentrated extract was then lyophilized. The residue was kept at $-20{ }^{\circ} \mathrm{C}$ for future use. Extract yield was approximately $11 \%$.

\section{Animals}

Male Wistar rats $( \pm 3$ months old), weighing between $270 \mathrm{~g}$ and $320 \mathrm{~g}$, from the University breeding colony (Animal House Holding, UFSM, Brazil) were kept in cages with free access to foods and water in a room with controlled temperature $\left(22{ }^{\circ} \mathrm{C} \pm 3\right)$ and in 12-h light/ dark cycle with lights on at 7:00 a.m. The animals were maintained and used in accordance to the guidelines of the Brazilian Association for Laboratory Animal Science.

\section{Preparation of tissue homogenates}

Rats were sacrificed by decapitation on the day of experiment and rapidly dissected to harvest the whole brain and liver which were then placed on ice and weighed. Tissues were immediately homogenized in ten volumes of cold $\left(4{ }^{\circ} \mathrm{C}\right)$ Tris- $\mathrm{HCl}(10 \mathrm{mM}, \mathrm{pH} 7.4)$. The homogenate was centrifuged for $10 \mathrm{~min}$ at $4000 \mathrm{~g}$ to yield a pellet that was discarded and a low-speed supernatant that was used in thiobarbituric acid reactive substances (TBARs) quantification.

\section{In vitro antioxidant/radical scavenging and metal ion chelating activities assays Total antioxidant activity}

Total antioxidant activity was determined by the ABTS test described by $\mathrm{Re}$ et al. [13]. The $\mathrm{ABTS}^{++}$radical cation was generated by mixing $7 \mathrm{mM}$ ABTS stock solution with $2.45 \mathrm{mM}$ potassium persulfate (final concentration) and incubating for $12-16 \mathrm{~h}$ in the dark at room temperature. The absorbance of the $\mathrm{ABTS}^{++}$solution was equilibrated to $0.70( \pm 0.02)$ by diluting with distilled water. ABTS $^{+}$solution $(1 \mathrm{ml})$ was mixed with $10 \mu \mathrm{l}$ of PBE dissolved in distilled water $(0,10,25,50$, 100 and $150 \mu \mathrm{g} / \mathrm{ml}$ final concentration) or Trolox standard dissolved in deionized water $(0,1,2.5,5.0,7.5$, and $10 \mu \mathrm{g} / \mathrm{ml}$ final concentration). The absorbance was measured at $734 \mathrm{~nm}$ after $6 \mathrm{~min}$. All experiments were carried out in replicates. The percentage inhibition of absorbance was calculated and plotted as a function of the concentration of standard and sample to determine the Trolox equivalent antioxidant concentration (TEAC). To calculate the TEAC, the straight line gradient of the plot for the sample was divided by that of Trolox (Additional file 1: Figure S1).

\section{$D P P H$ radical scavenging activity of extract}

DPPH radical-scavenging activities of $P$. biglobosa extract and reference compound (Ascorbic acid) were determined as described by Batool et al. [14]. The capacity of extracts to scavenge the lipid-soluble 2, 2- diphenyl-1-picrylhydrazyl (DPPH) radical, which results in the bleaching of the purple colour exhibited by the stable DPPH radical, could be monitored at $517 \mathrm{~nm}$.

Briefly, PBE $(0,10,25,50,100$, and $250 \mu \mathrm{g} / \mathrm{ml})$ or the reference compound, ascorbic acid $(0,10,20,30,40$ and $50 \mu \mathrm{g} / \mathrm{ml}$ ) was added to an ethanol solution of DPPH (0.03 mM). The mixture was shaken and left to stand at room temperature for $30 \mathrm{~min}$. The absorbance of the resulting solution was measured spectrophotometrically at $517 \mathrm{~nm}$. The radical scavenging activity was calculated as a percentage of $\mathrm{DPPH}^{\cdot}$ discolouration.

\section{Reducing power}

The $\mathrm{Fe}^{3+}$ - reducing power of the extract was determined as described by Oyaizu [15] with a slight modification. Different concentrations $(0.0-200 \mu \mathrm{g} / \mathrm{mL})$ of the extract $(0.5 \mathrm{~mL})$ were mixed with $0.5 \mathrm{~mL}$ phosphate buffer (0.2 M, pH 6.6) and $0.5 \mathrm{~mL}$ potassium hexacyanoferrate (0.1\%), followed by incubation at $50{ }^{\circ} \mathrm{C}$ in a water bath for $20 \mathrm{~min}$. After incubation, $0.5 \mathrm{~mL}$ of TCA (10\%) was added to terminate the reaction. The upper portion of the solution $(1 \mathrm{~mL})$ was mixed with $1 \mathrm{~mL}$ distilled water, and $0.1 \mathrm{~mL} \mathrm{FeCl}_{3}$ solution (1\%) was added. The reaction mixture was left for $10 \mathrm{~min}$ at room temperature and the absorbance was measured at $700 \mathrm{~nm}$ against an appropriate blank solution. All tests were performed three times. A higher absorbance of the reaction mixture indicated greater reducing power. Butylated hydroxytoluene (BHT) was used as a positive control.

\section{$\mathrm{Fe}^{2+}$ chelation}

The ferrous ion chelating activity of extract was evaluated by a standard method [16] with minor changes. The reaction was carried out in Tris-HCL buffer $(0.1 \mathrm{M}$, $\mathrm{pH}$ 7.5). Briefly, various concentrations $(0-200 \mu \mathrm{g} / \mathrm{mL})$ of plant extract were added to $100 \mu \mathrm{M}$ ferrous sulfate solution. The reaction mixture was incubated for $30 \mathrm{~s}$, before the addition of 1,10 -Phenanthroline $(0.25 \% \mathrm{w} / \mathrm{v})$. The absorbance was subsequently measured at $510 \mathrm{~nm}$ in a spectrophotometer. EDTA was used as a positive control.

\section{Hydroxyl radical scavenging}

This was assayed by a standard method [17]. Deoxyribose is degraded by hydroxyl radicals with the release of thiobarbituric acid (TBA) reactive materials. The assay was based on the generation of hydroxyl radical by the $\mathrm{Fe}^{2+}-\mathrm{H}_{2} \mathrm{O}_{2}$ system (the Fenton reaction) and quantification of the degradation product of 2-deoxyribose by condensation with TBA.

The reaction mixture contained $120 \mu$ l of 2-deoxy-2ribose $(3 \mathrm{mM}) ; 80 \mu \mathrm{l}$ of potassium phosphate buffer (50 mM, pH 7.4); $80 \mu \mathrm{l}$ of $\mathrm{FeSO}_{4}(100 \mu \mathrm{M}) ; 80 \mu \mathrm{l}$ of $\mathrm{H}_{2} \mathrm{O}_{2}(1.0 \mathrm{mM})$ and $40 \mu \mathrm{l}$ of $\operatorname{PBE}(0,25,50,100,150$, 
and $200 \mu \mathrm{g} / \mathrm{ml}$ ) of the test sample and distilled water to make up a final volume of $1 \mathrm{ml}$. After incubation for $1 \mathrm{~h}$ at $37{ }^{\circ} \mathrm{C}, 0.5 \mathrm{ml}$ of the reaction mixture was added to $1 \mathrm{ml}$ of $2.8 \%(w / v)$ TCA, then $1 \mathrm{ml}$ of $1 \%$ aqueous TBA was added. The mixture was incubated at $90{ }^{\circ} \mathrm{C}$ for $15 \mathrm{~min}$. After cooling, the absorbance was measured at $532 \mathrm{~nm}$ against an appropriate blank solution. The percentage inhibition was evaluated by comparing the test and blank solutions.

\section{Evaluation of membrane lipid peroxidation}

Quantification of thiobarbituric acid reactive substances (TBARs) production, an index of biological membrane peroxidation, was determined as described by Puntel et al. [16]. Briefly, $20 \mu \mathrm{L}$ of PBE $(50-250 \mu \mathrm{g} / \mathrm{mL})$ and prooxidant agent $\left(100 \mu \mathrm{m} \mathrm{Fe}{ }^{2+}\right)$ were added to $100 \mu \mathrm{L}$ of rat liver or brain tissue homogenate in Tris-HCL buffer (10 mM; pH 7.4). The reaction mixture was incubated at $37{ }^{\circ} \mathrm{C}$ in a water bath. Color reaction was developed by adding $200 \mu \mathrm{L}$ of $8.1 \%$ sodium dodecyl sulfate (SDS) to the reaction mixture. This was subsequently followed by the addition of $500 \mu \mathrm{L}$ of acetic acid/ $\mathrm{HCl}$ buffer $(1.34 \mathrm{M}$; $\mathrm{pH}$ 3.4) and $500 \mu \mathrm{L} 0.6 \%$ thiobarbituric acid (TBA). The mixture was incubated at $100{ }^{\circ} \mathrm{C}$ for $1 \mathrm{~h}$. TBARs produced were measured at $532 \mathrm{~nm}$ and the absorbance was compared with a malondialdehyde (MDA) standard curve.

\section{Angiotensin-converting enzyme (ACE) inhibition assay}

The assay was based on the hydrolysis of N-hippurylHis-Leu hydrate (HHL) by the angiotensin-converting enzyme as described by Cushman and Cheung [18]. Briefly, the enzyme source was prepared with freshly removed rat lung. The tissue was homogenised in cold $125 \mathrm{mM}$ Tris buffer, $\mathrm{pH} 8.3(1 / 10, w / v)$ and centrifuged at $4{ }^{\circ} \mathrm{C}$ for $10 \mathrm{~min}$ at $4000 \mathrm{~g}$ to yield a low-speed supernatant. The reaction mixture contains $40 \mu \mathrm{L}$ Tris- $\mathrm{HCl}$ buffer $(125 \mathrm{mM}, \mathrm{pH} 8.3)$, enzyme source $(50 \mu \mathrm{L})$ and $10 \mu \mathrm{L}$ extracts/drug (PBE- 25, 50, $100 \mu \mathrm{g} / \mathrm{mL}$; ramipril$0.04,0.2,0.4 \mu \mathrm{g} / \mathrm{mL})$. This was incubated at $37{ }^{\circ} \mathrm{C}$ for $15 \mathrm{~min}$. Thereafter, ACE substrate, HHL $(8.3 \mathrm{mM}$; $150 \mu \mathrm{l})$ was added and further incubated for $30 \mathrm{~min}$ at the same temperature in a shaker. The enzymic reactions were terminated by addition of $1 \mathrm{ml}$ of $1 \mathrm{M} \mathrm{HCI}$. The hippuric acid formed by the action of the angiotensin-converting enzyme on HHL was extracted from the acidified solution into $1-2 \mathrm{ml}$ of ethyl acetate by vortex mixing for $15 \mathrm{~s}$. After centrifugation at $3000 \mathrm{~g}$ for $5 \mathrm{~min}$, an $1 \mathrm{ml}$ aliquot of each ethyl acetate layer was transferred into a clean tube. The ethyl acetate fractions were evaporated by heating at $120{ }^{\circ} \mathrm{C}$ for $30 \mathrm{~min}$ in a Temp-Blok module heater. The hippuric acid was re-dissolved in $1 \mathrm{ml}$ distilled water and the amount formed was determined from its absorbance at $228 \mathrm{~nm}$ wavelength.

\section{Isolation of hepatic mitochondria}

Liver mitochondria were isolated as previously described [19]. Wistar rats were killed by decapitation and the liver tissues were rapidly removed and placed on ice-cold isolation buffer containing $225 \mathrm{mM}$ mannitol, $75 \mathrm{mM}$ sucrose, $1 \mathrm{mM}$ ethylene glycol-bis( $\beta$-aminoethyl ether)$\mathrm{N}, \mathrm{N}, \mathrm{N}^{\prime}, \mathrm{N}^{\prime}$-tetraacetic acid (EGTA), $0.1 \%$ bovine serum albumin (BSA; free fatty acid) and $10 \mathrm{mM}$ HEPES $\mathrm{pH}$ 7.2. The tissues were then homogenized and the resulting suspension centrifuged for $7 \mathrm{~min}$ at 2,000Xg. Next, the supernatant was centrifuged for $10 \mathrm{~min}$ at $12,000 \mathrm{Xg}$. The pellet was re-suspended in isolation buffer II containing $225 \mathrm{mM}$ mannitol, $75 \mathrm{mM}$ sucrose, $1 \mathrm{mM}$ EGTA and $10 \mathrm{mM}$ HEPES pH 7.2 and centrifuged at $12,000 \mathrm{Xg}$ for $10 \mathrm{~min}$. Finally, the last supernatant was discarded, and the pellet was re-suspended and maintained in buffer III (sucrose $100 \mathrm{mM}, \mathrm{KCl} 65 \mathrm{mM}$, $\mathrm{K}^{+}$-HEPES $10 \mathrm{mM}$ and EGTA $50 \mu \mathrm{M}$ pH 7.2) to a protein concentration of $0.5 \mathrm{mg} / \mathrm{mL}$ for subsequent analyses. Protein concentration was measured by the method described by Lowry et al. [20] using bovine serum albumin (BSA) as standard.

\section{Measurement of mitochondrial membrane potential $(\Delta \psi m)$}

Mitochondrial membrane potential was estimated by fluorescence changes of safranine recorded by spectrofluorimeter [19]. The cuvette inside the spectrofluorimeter contains $3 \mathrm{~mL}$ of buffer III to which an aliquot $(30 \mathrm{~mL})$ of the isolated mitochondria (approximately $500 \mathrm{mg}$ protein) was added. The reaction was started by the addition of safranine $(67 \mathrm{mM})$ and succinate $(1.5 \mathrm{M})$ added after $10 \mathrm{~s}$. The fluorescence was monitored for $200 \mathrm{~s}$ after which $10 \mu \mathrm{L}$ of extract/drug (PBE: 25, 50, $100 \mu \mathrm{g} / \mathrm{mL}$; catechin: $1,5,10 \mu \mathrm{g} / \mathrm{mL}$ ) or distilled water (for control) was added and allowed for additional $150 \mathrm{~s}$. Finally 2,4-dinitrophenol, DNP $(100 \mathrm{mM}, 30 \mu \mathrm{L})$ was added to uncouple oxidative phosphorylation and inhibit adenosine triphosphate production. The change in fluorescence was recorded by a RF-5301 Shimadzu spectrofluorimeter (Kyoto, Japan) operating at excitation and emission wavelengths of $495 \mathrm{~nm}$ and $586 \mathrm{~nm}$, respectively, with slit widths of $3 \mathrm{~nm}$. The potential difference $(\Delta \Psi \mathrm{m})$ was obtained by the difference between the fluorescence intensity prior to and after DNP addition.

\section{Evaluation of reactive species (RS) formation with $D C H$ (dichlorofluorescein-reactive species (DCH-RS)}

RS levels were measured using the oxidant sensing fluorescent probe, $2^{\prime}, 7^{\prime}$-dichlorofluorescein diacetate (DCHFDA) [21]. The oxidation of DCHF-DA to fluorescent dichlorofluorescein (DCF) was determined at $488 \mathrm{~nm}$ for excitation and $525 \mathrm{~nm}$ for emission. An aliquot of $5 \mu \mathrm{L}$ (50 $\mu \mathrm{g} /$ protein) of the homogenate of the isolated mitochondria was added to $3 \mathrm{~mL}$ of buffer III (containing 
$5 \mathrm{mM}$ succinate). The reaction medium was exposed to $\operatorname{PBE}(25,50,100 \mu \mathrm{g} / \mathrm{mL})$ or catechin $(1,5,10 \mu \mathrm{g} / \mathrm{mL})$ with or without $\mathrm{Ca}^{2+}(80 \mu \mathrm{M})$ or SNP $(150 \mu \mathrm{M})$. After $10 \mathrm{~s}$, DCHF-DA $(10 \mu \mathrm{M}$, in absolute ethanol) was added to the mixture and the fluorescence intensity from DCF was measured for $300 \mathrm{~s}$. Values of mitochondrial membrane potential $(\Delta \psi \mathrm{m})$ were expressed as percent of control.

\section{Statistical analysis}

Results calculated from triplicate data were expressed as means \pm standard error of means (SEM). With the exception of data on mitochondrial ROS production which was analysed using two-way ANOVA followed by Bonferroni post test, data were analyzed using one-way analysis of variance followed by Neuman-Keuls comparison of means. The significance level was set at $p<0.05$. Statistical analysis, graphing and $\mathrm{EC}_{50} / \mathrm{IC}_{50}$ (median effective concentration/median inhibitory concentration) determination were done using Graph Pad Prism (ver.5.0a).

\section{Results}

Radical scavenging, ferric reducing and metal-chelating properties of $P$. biglobosa extract (PBE)

The suppression of ABTS radical cation following interaction with PBE or trolox was concentration-dependent and statistically significant $(P<0.001$; Fig. 1a). The
ABTS scavenging potency of PBE was reflected by its trolox equivalent antioxidant concentration (TEAC) value $(0.06 \pm 0.001)$, just as its $\mathrm{EC}_{50}(45.30 \pm 0.1 \mu \mathrm{g} / \mathrm{ml})$ further showed the extract was less potent than the pure reference compound $(4.5 \pm 0.1 \mu \mathrm{g} / \mathrm{ml})$. PBE produced concentration-dependent discolouration of the purple colour due to $\mathrm{DPPH}$ radical with an $\mathrm{EC}_{50}$ value of $98.33 \pm 1.0 \mu \mathrm{g} / \mathrm{ml}$ compared with $12.5 \pm 0.4 \mu \mathrm{g} / \mathrm{ml}$ for the reference ascorbic acid (Fig. 1b, Table 1). As shown in Fig. 1c, the reduction of $\mathrm{Fe}^{3+}$ to $\mathrm{Fe}^{2+}$ increased with increasing concentration of $\mathrm{PBE}$ and was highest $(0.89 \pm 0.06)$ at $200 \mu \mathrm{g} / \mathrm{mL}$ final concentration. The extract of $P$. biglobosa possesses moderate but dosedependent $\mathrm{Fe}$ (II) chelating activity with over 40\% chelation at $200 \mu \mathrm{g} / \mathrm{mL}$ extract concentration. This was however considerably lower than that of the standard EDTA with about $54 \%$ chelation at $50 \mu \mathrm{g} / \mathrm{mL}$ concentration (Fig. 1d).

\section{Effects of PBE on hydroxyl radical $(\mathrm{OH})$ generation and $\mathrm{Fe}^{2+} / \mathrm{SNP}$-induced membrane peroxidation}

$P$. biglobosa caused only a weak inhibition of deoxyribose degradation (Fig. 2a; $P<0.001)$. PBE $(50 \mu \mathrm{g} / \mathrm{mL})$ caused a maximal inhibition of $15 \%$, whereas higher concentrations of extract had lesser efficacy. Fe(II) significantly increased TBARs content to about $88 \%$ and a

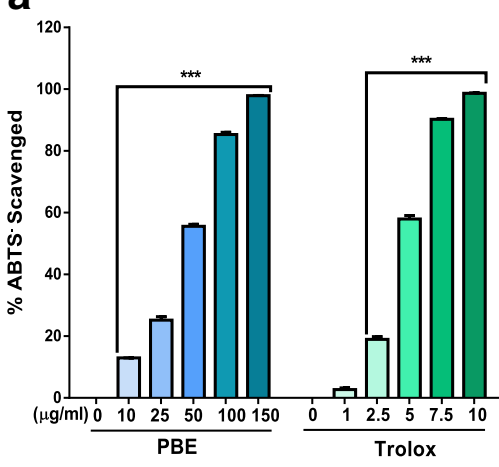

C

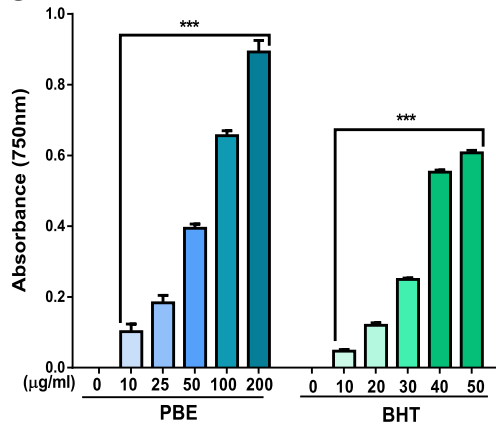

b

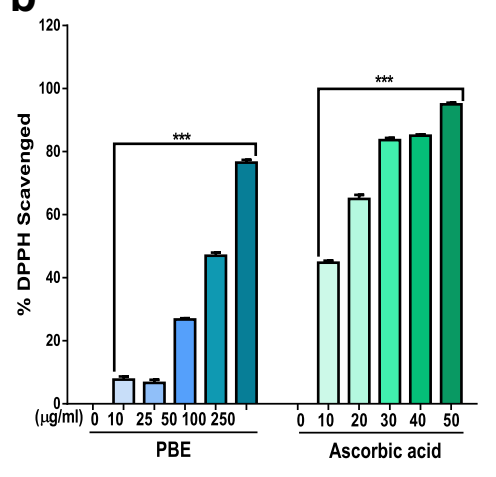

d

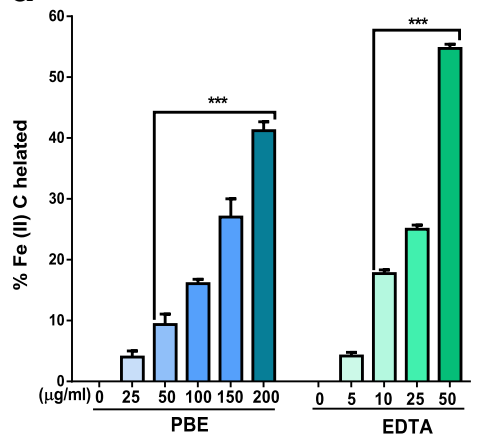

Fig. 1 ABTS (a), DPPH (b) radicals scavenging, reducing property (c) and Fe(II)-chelating potential (d) of P. biglobosa leaf extract. Results are mean \pm SEM of three parallel measurements. $P$ value: ${ }^{* * *} P<0.001$ vs $0 \mu \mathrm{g} / \mathrm{ml}$. PBE = Parkia biglobosa leaf aqueous-methanol extract; $\mathrm{BHT}=$ butylated hydroxytoluene; EDTA $=$ ethylenediaminetetraacetic acid 
Table $1 E C_{50}$ values of aqueous-methanolic extract of $P$. biglobosa leaf for ABTS, DPPH radicals scavenging, toxicant-induced lipid peroxidation and $I C_{50}$ for Angiotensin-1-converting enzyme inhibition in vitro

\begin{tabular}{ll}
\hline Parameter & EC50/lC50 $(\mu \mathrm{g} / \mathrm{ml})$ \\
\hline ABTS Radical Scavenging & $45.30 \pm 0.1$ \\
DPPH Radical Scavenging & $98.33 \pm 1.0$ \\
Fe2 + -Induced lipid peroxidation & \\
$\quad$ Liver & $75.87 \pm 2.1$ \\
$\quad$ Brain & $89.34 \pm 2.5$ \\
SNP-Induced lipid peroxidation & \\
$\quad$ Liver & $28.10 \pm 1.6$ \\
$\quad$ Brain & $17.25 \pm 0.8$ \\
Angiotensin-1-converting enzyme & $51.30 \pm 5.1$ \\
\hline
\end{tabular}

Values are mean \pm SD of three parallel measurements

$85 \%$ of the basals in isolated rats' liver and brain homogenates respectively (Fig. 2b, c; $\mathrm{P}<0.001$ ). Treatment of tissue homogenates with SNP $(5 \mu \mathrm{M})$ also caused the accumulation of lipid peroxides as manifested by up to $90 \%$ and $85 \%$ increase in MDA content of the liver and brain respectively when compared to the respective basal homogenates. The extract showed $\mathrm{EC}_{50}$ values $(\mu \mathrm{g} / \mathrm{ml})$ of $75.87 \pm 2.05$ and $89.34 \pm 2.52$ in liver and brain respectively for the mitigation of Fe (II) peroxidation and $\mathrm{EC}_{50}$ values of $28.1 \pm 1.59$ and $17.25 \pm 0.78$ in the respective tissues for that of SNP. It is therefore noteworthy that on the basis of median effective concentrations $\left(\mathrm{EC}_{50}\right)$, the extract afforded greater protection against SNP-induction when compared to iron-induced lipid peroxidation.

\section{Effect of $P$. biglobosa extract on angiotensin-I-converting enzyme}

The inhibition of angiotensin-I-converting enzyme by $P$. biglobosa aqueous-methanolic extract was dosedependent and significant $(P<0.01 / P<0.05)$ in vitro (Fig. 3). The crude extract showed $\mathrm{IC}_{50}$ value of $51.30 \pm 5.1 \mu \mathrm{g} / \mathrm{mL}$ for the inhibition of ACE (Table 1). This was considerably higher than the value $(0.17 \pm 0.04 \mu \mathrm{g} / \mathrm{mL})$ observed for the reference standard.

\section{Modulatory effect of $P$. biglobosa extract on hepatic mitochondrial membrane potential}

Catechin at the study doses had no significant effect on the membrane potential of isolated liver mitochondria. PBE caused slight depolarization of the membrane potential of rats' liver mitochondria. Reduction of the mitochondrial potential difference by PBE was however statistically significant $(P<0.05)$ at $100 \mu \mathrm{g} / \mathrm{mL}$ final concentration (Fig. 4).
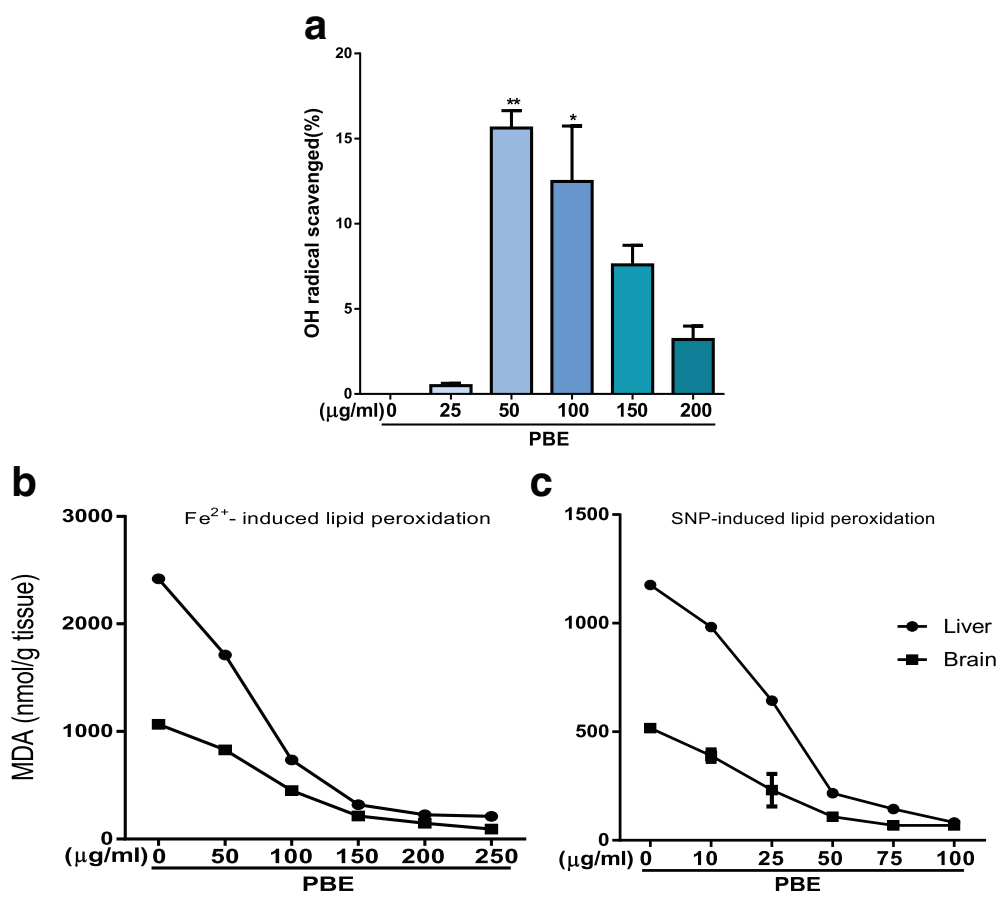

Fig. 2 Hydroxyl radical scavenging activity (a) and inhibition of $\mathrm{Fe}^{2+}-(\mathbf{b})$ and SNP-induced (c) lipid peroxidation in rat tissues by P. biglobosa leaf extract. Results are mean \pm SEM of three parallel measurements 


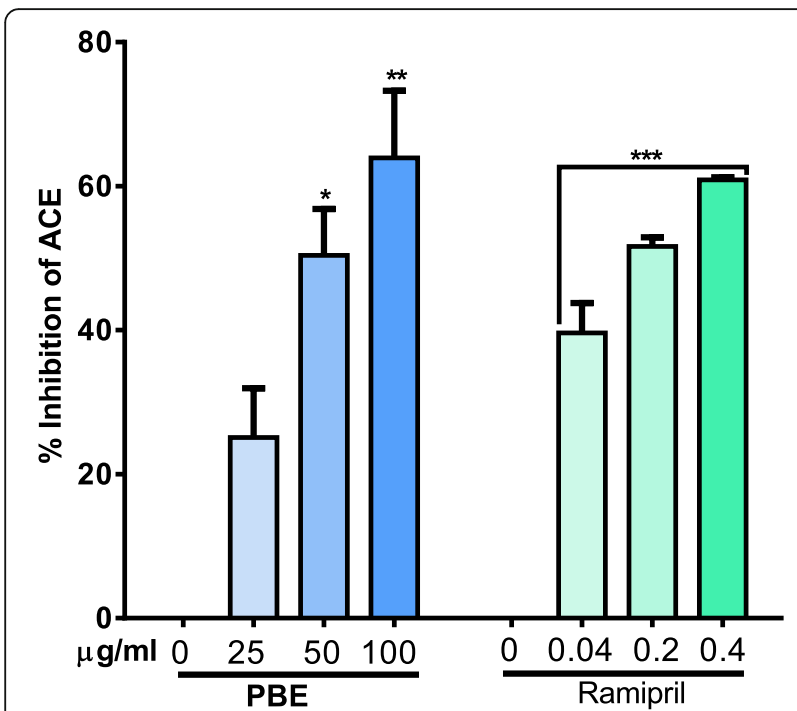

Fig. 3 Inhibition of angiotensin-1-converting enzyme by P. biglobosa leaf extract in vitro. Results are mean \pm SEM of three parallel measurements. ${ }^{* * *} P<0.001$ vs $0 \mu \mathrm{g} / \mathrm{ml}$

\section{Effects of PBE on $\mathrm{Ca}^{2+} / \mathrm{SNP}$-induced mitochondrial reactive species (RS) generation}

As shown in Fig. 5, basal mitochondrial RS formation in the liver was significantly reduced $(P<0.001)$ by treatment with all concentrations of PBE under study when compared to the level found in the control. $\mathrm{Ca}^{2+}$ and SNP- dependent surge in mitochondrial production of RS was more efficiently attenuated by PBE than catechin. Concentration of catechin used in the present study was based on the proportion of catechin in crude extract as previously documented [11].

\section{Discussion}

Many of the therapeutic actions of phytochemicals are thought to be associated with their biologically active polyphenol components, such as flavonoids and phenolic acids, which possess powerful antioxidant activities [22]. In the present study, the radical scavenging activity of $P$. biglobosa extract was evaluated using different radical systems in vitro as it has been proposed that the efficacy and the antioxidant potency of some extracts may vary depending on the pro-oxidant used [23]. As a principle, spectrophotometric measurement of the colour change of the DPPH solution from purple to yellow as the radical is quenched by the antioxidant gives a quantitative estimation of the antioxidant. Hence it could be proposed that reactions of antioxidant, hydrogen donors in $P$. biglobosa with DPPH radicals reduce the latter to the corresponding hydrazine [19]. A similar proposition could also be put forward for the decolourization of the ABTS radicals following exposure to PBE. Potential antioxidant activity has been reported to be concomitant with the reducing power of a plant extract. $P$. biglobosa leaf extract possesses considerable reducing property as demonstrated by its concentration-dependent ability to reduce $\mathrm{Fe}^{3+}$ to $\mathrm{Fe}^{2+}$. In this case, the phenolics in the leaf could act as reducing agents by donating electrons to free radicals and terminating the free radical-mediated chain reactions [24]. Iron can promote lipid peroxidation by decomposing lipid hydroperoxides into peroxyl and alkoxyl radicals that can perpetuate the chain reaction and via the Fenton reaction. Metal chelating agents reduce the concentration of metal ions in the Fenton-type reaction and thus would protect the system from oxidative damage through inhibition of metal-dependent processes [25]. Understandably, P. biglobosa extract was not as potent as EDTA in iron chelation because the metal-chelating efficiency of the phytochemicals (notably polyphenols) involved are usually lower than those of standard chelators like EDTA [26].

In the present study, the inhibitory effects of PBE against $\mathrm{Fe}^{2+}$ and SNP-induced lipid peroxidation were assessed. Lipid peroxidation is a free radical-mediated process involving lipid-derived radicals, such as alkoxyl and peroxyl radicals, wherein oxidative damage is propagated to polyunsaturated fatty acids. The toxicity of Fe (II) proceeds via the Fenton reaction where iron catalyses one-electron transfer reactions that generate reactive oxygen species, such as the $\mathrm{OH}^{-}$from $\mathrm{H}_{2} \mathrm{O}_{2}$. Iron is capable of decomposing lipid peroxides leading to the generation of peroxyl and alkoxyl radicals and favouring the propagation of lipid oxidation [25]. Sodium nitroprusside (SNP), on the other hand, has been reported to cause cytotoxicity through the release of cyanide and/or nitric oxide [27]. The released NO is capable of causing neuronal damage in cooperation with other reactive oxygen species (ROS) notably superoxide radical to form peroxynitrite radical [28]. The considerable inhibition of SNP-induced lipid peroxidation by PBE could be attributed to the ability of the extract to scavenge $\mathrm{NO}^{\circ}$ radical produced by the SNP, thus protecting the tissues against oxidative insults [28].

The present study revealed that $P$. biglobosa extract exerts concentration-dependent and inhibition of both iron- and SNP-induced peroxidation in liver and brain homogenates. The protections offered by $P$. biglobosa suggest that the hydromethanolic extract may protect the liver and brain against toxicities resulting from a potential overload of iron and nitric oxide. Angiotensinconverting enzyme (ACE) is responsible for producing the potent vasoconstrictor and trophic angiotensin II (AII). AII increases blood pressure by its action as a potent vasoconstrictive substance and by stimulating the production of aldosterone, which promotes sodium and water retention in the body. ACE-inhibitory substances are thus desirable when the aim is to achieve lower blood pressure. In the present study, PBE demonstrated 

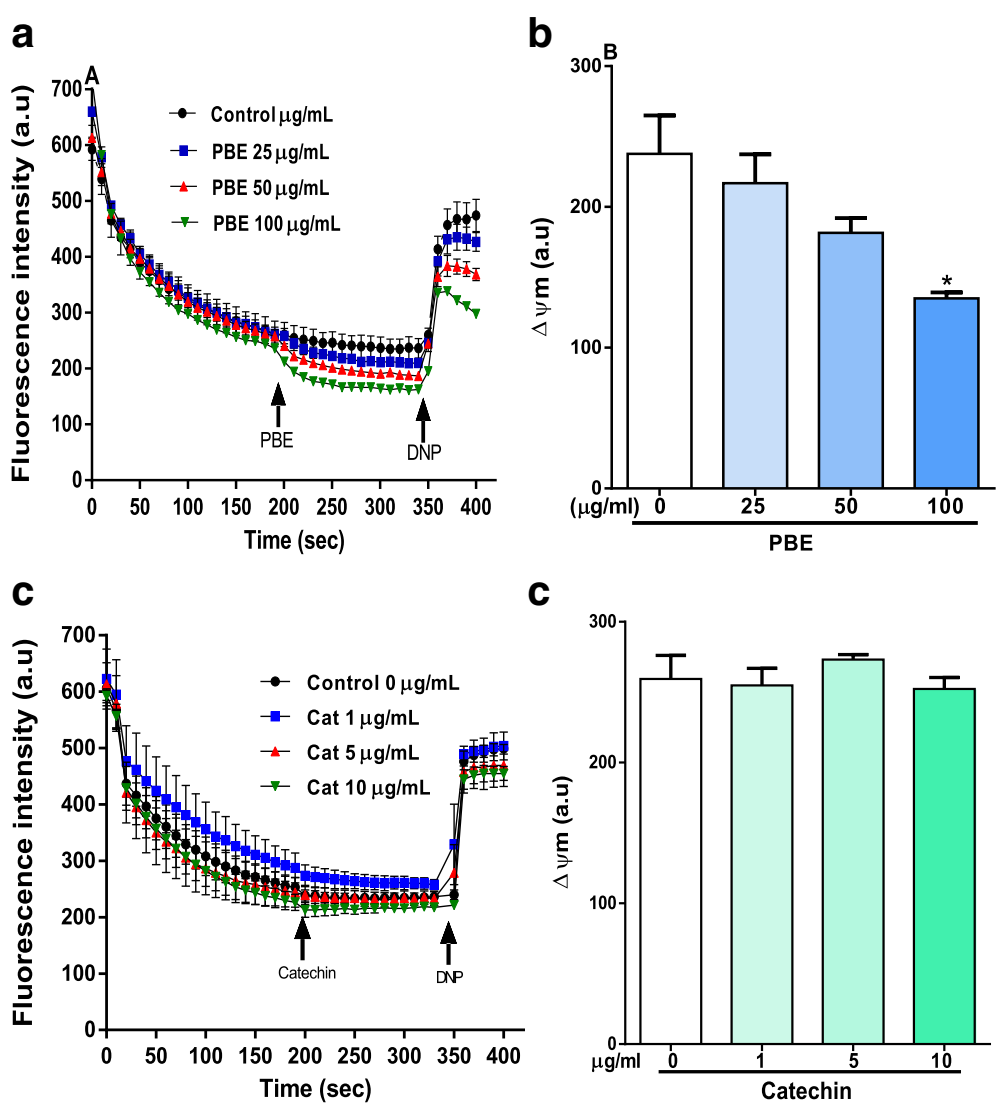

Fig. 4 Effects of Parkia biglobosa leaf extract (PBE) ( $\mathbf{a}$ and $\mathbf{b}$ and catechin (c and $\mathbf{d}$ ) respectively on membrane potential difference of isolated liver mitochondria. Data is presented as mean \pm SEM of three assays performed in triplicates using independent mitochondrial preparations. ${ }^{*} P<0.05$ vs $0 \mu \mathrm{g} / \mathrm{ml}$

ACE- inhibitory effect, a phenomenon that could be involved in its documented hypotensive potential under experimental condition [12]. The phytochemicals responsible for the ACE-inhibitory effect of still remains to be elucidated. Hypothetically, however, the polyphenolic constituents of the leaf could be involved. Free hydroxyl groups of phenolic compounds are important structural moieties capable of chelating the zinc ions in ACE active sites, thus inactivating the enzyme [29]. Several flavonoids have thus been shown to demonstrate competitive inhibition towards ACE [30]. It is noteworthy that the ACE inhibitory activity of the crude extract is much lower than that recorded for the standard drug, Ramipril. Crude extracts are known to contain various phytochemical constituents capable of interfering with one another to produce antagonistic or synergistic effects. Pure compounds, on the other hand, are devoid of negative interactions. A higher ACE-inhibitory potency could, therefore, be recorded with the pure form(s) of the phytochemical(s) responsible for the effect.

SNP is a NO donor compound that reportedly exhibited a deleterious effect on mitochondrial function and survival of synoviocytes [31] while reducing the activity of complex IV of the mitochondrial electron transport chain (MTC) with consequent apoptotic cell death [32]. The toxicity of $\mathrm{NO}$ is dependent on its reaction with the superoxide anion radical $\left(\mathrm{O}^{--}\right)$which yield peroxynitrite, a highly cytotoxic ROS. Peroxynitrite is further decomposed to the hydroxyl radical which eventually leads to lipid peroxidation, protein oxidation, and DNA damage [33]. Mitochondrial dysfunction has been suggested as the underlying mechanism of NO-mediated toxicity [34]. In the present study, PBE and its major polyphenolic constituent, catechin attenuated SNP-induced increase in the rate of mitochondrial reactive species formation possibly due to their free radical scavenging effects.

Disruption of calcium homeostasis and free radicals generation are among the detrimental effects associated with the toxicity of some compounds [35]. Formation of ROS by mitochondria is enhanced as a consequence of increased cytosolic calcium concentrations $([\mathrm{Ca} 2+])[36]$. In the present study, calcium-induced reactive species formation in the mitochondria was attenuated by PBE and catechin. Catechin was selected as the reference phenolic because it was previously reported to be 

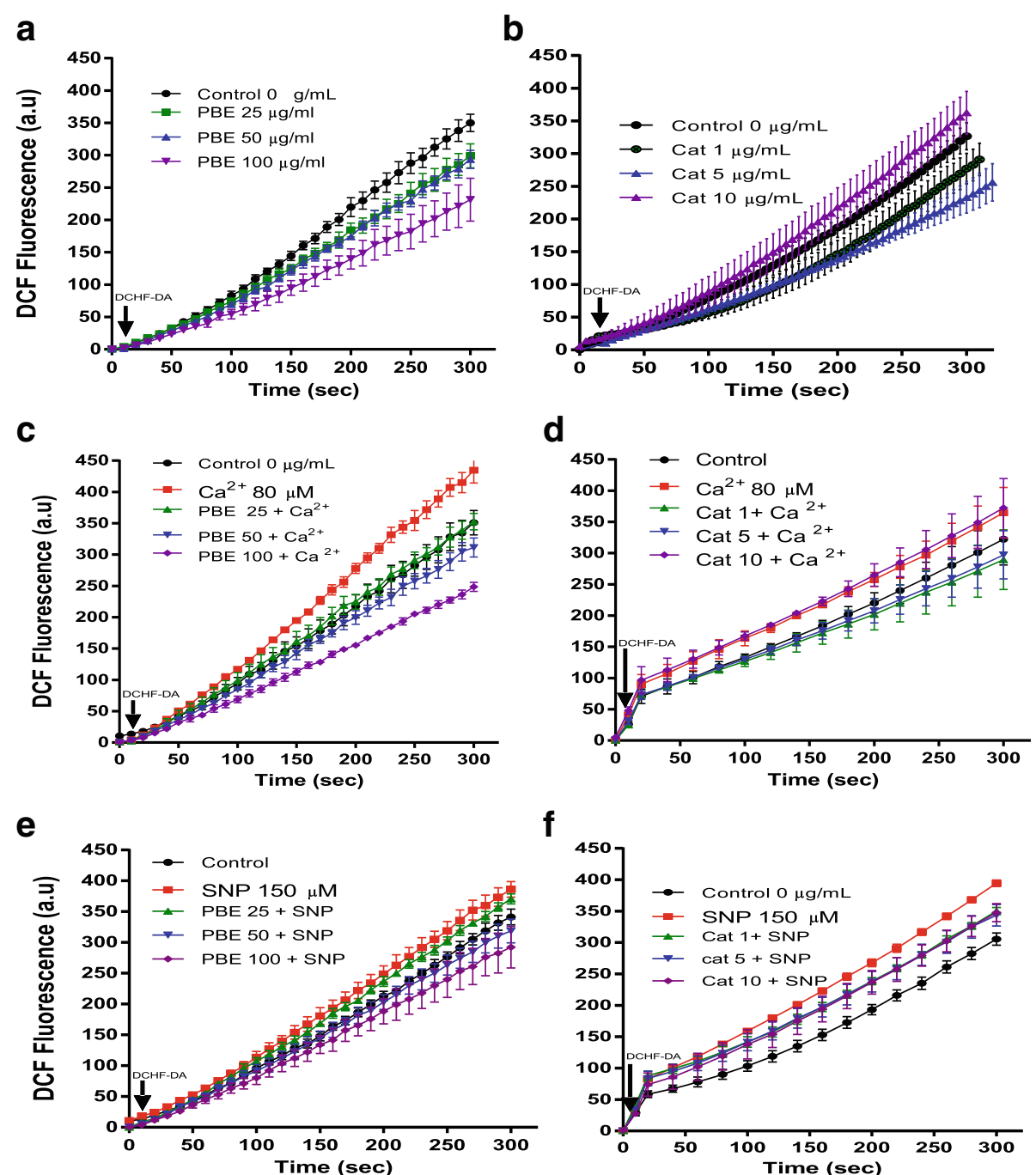

Fig. 5 Respective effect of Parkia biglobosa leaf extract (PBE) and catechin on basal ROS production (a and $\mathbf{b}$ ), Ca ${ }^{2+}$ - induced (c and $\left.\mathbf{d}\right)$ and SNP-induced (e and $\mathbf{f}$ ) aggravation of ROS generation in isolated rats' liver mitochondria. Data is presented as mean \pm SEM of three assays performed in triplicates using independent mitochondrial preparations. a PBE 25-, 50-, $100 \mu \mathrm{gg} / \mathrm{ml}(P<0.001$ vs Control), (b) Cat 1-, 5-, $10 \mu \mathrm{mg} / \mathrm{ml}$ non-significant vs control $(P>0.05)$, (c) $\mathrm{Ca}^{2+} 80 \mu \mathrm{M}, \mathrm{PBE} 100 \mu \mathrm{g} / \mathrm{ml}\left(P<0.001 \mathrm{vs}\right.$ control), (d) $\mathrm{Ca}^{2+} 80 \mu \mathrm{M}$, Cat $10 \mu \mathrm{g} / \mathrm{ml}(P<0.01$ vs control), (e) SNP ( $P<0.01$ vs control), PBE $25 \mu \mathrm{g} / \mathrm{ml}(P<0.05$ vs control), (f) SNP $(P<0.001$ vs control)

present in high amount in PBE [11]. Catechins possess strong metal ion chelating potentials due to their catechol structures and have been shown to form stable complexes with ions, including $\mathrm{Fe}^{2+}$ and $\mathrm{Ca}^{2+}$ [37]. Therefore, the reduction of a calcium-induced surge in mitochondrial ROS production by PBE might be related to the ability of the constituent phenolics to scavenge free radicals and chelate metal ion. Mitochondrial membrane potential $(\Delta \Psi \mathrm{m})$ contributes to determining a driving force for calcium to enter the mitochondria. ROS formation in mitochondria occurs at high membrane potentials. Mild depolarization of the mitochondrial potential by PBE does not involve the constituent catechin as revealed in the present study. Some activities in herbs may be attributable to other unidentified substances or to synergistic interactions among constituents. Even though the mechanism controlling the mitochondrial membrane potential $\Delta \Psi \mathrm{m}$ in vivo are complex and not fully understood, 'mild un-coupling' of mitochondria are turned on in vivo to diminish the formation of ROS [38]. Decreased $\Delta \Psi \mathrm{m}$, due to the uncoupling of electron flow from ATP synthesis by increased proton permeability of the inner mitochondrial membrane, can reduce ROS production at complex I by decreasing $\mathrm{NAD}(\mathrm{P}) \mathrm{H} / \mathrm{NAD}(\mathrm{P})^{+}$and possibly by decreasing the life span of the semiquinone radical [39]. Such decrease in the mitochondrial membrane potential $(\Delta \Psi \mathrm{m})$ primarily attenuates mitochondrial $\mathrm{RO}$ production with a consequential decrease in mitochondrial $\mathrm{Ca}^{2+}$ uptake [40], preventing mitochondrial calcium overload and the 
subsequent apoptosis [41]. This might account for the superior mitochondrial ROS mitigating property of PBE over catechin. Such mild depolarization has been attributed to the neuroprotective effect of a plant extract [42] and the protection of cardiomyocytes from oxidative stress [40]. In the case of $\mathrm{PBE}$, further studies are warranted to identify the active molecules and the underlying mechanisms involved in its mild mitochondrial potential depolarization propensity.

\section{Conclusion}

In summary, the results presented here suggest that Parkia biglobosa leaf did exhibit considerable antioxidant activity and ACE inhibition in vitro. It also modulated mitochondrial functions by attenuating toxicant induced ROS generation, with slight mitochondrial membrane depolarization propensity. The phenolic constituents could be actively involved in these effects. Since the findings are largely under in vitro conditions, further studies are needed to make appropriate assumptions about the safety and effectiveness of the plant as hypotensive agent in mammals under in vivo conditions, and to fully characterize the biological potential of the plant.

\section{Additional file}

Additional file 1: Figure S1. Determination of the trolox equivalent antioxidant concentration (TEAC) value for PBE. Values are mean $\pm \mathrm{SEM}$ of three parallel measurements. (DOC $61 \mathrm{~kb}$ )

\section{Abbreviations}

ABTS: 2,2'-azino-bis(3-ethylbenzothiazoline-6-sulfonic acid); ACE: AngiotensinI-converting enzyme; BHT: Butylated hydroxytoluene; DCFH: 2', 7'dichlorodihydrofluorescin; DCFHDA: dichlorofluorescin diacetate; DPPH: 1,1diphenyl-2-picrylhydrazyl; EDTA: Ethylenediaminetetraacetic acid; EGTA: Ethylene glycol-bis ( $\beta$-aminoethyl ether)- $\mathrm{N}, \mathrm{N}, \mathrm{N}^{\prime}, \mathrm{N}^{\prime}$-tetraacetic acid; PBE: Aqueous-methanolic extract of $P$. biglobosa leaf; SNP: Sodium nitroprusside; TBA: Thiobarbituric acid

\section{Acknowledgements}

Authors wish to acknowledge the doctoral fellowship (FR number: $3,240,256,075)$ and financial support granted one of us (KK) by TWAS-CNPq.

\section{Authors' contributions}

MTO, JBTR and AAA were involved in the planning of the research as well as the technical design. KK collected sample, performed the experimental works in the laboratory, analyzed the data and drafted the manuscript. RTK and ACA assisted in the laboratory work and data analysis. JBTR and MTO were also involved in the interpretation of the results and revision of the whole manuscript with grammatical checking.

\section{Competing interests}

The authors declare that they have no competing interest.

\section{Publisher's Note}

Springer Nature remains neutral with regard to jurisdictional claims in published maps and institutional affiliations.

\section{Author details}

'Department of Biochemistry, School of Sciences, The Federal University of Technology, Akure PMB 704, Nigeria. ${ }^{2}$ Department of Biochemistry, Faculty of Science, Federal University Oye-Ekiti, Oye-Ekiti PMB 373, Nigeria. ${ }^{3}$ Department of Biochemistry and Molecular Biology, CCNE, Federal University of Santa Maria, Santa Maria, RS 97105-900, Brazil.

Received: 22 June 2017 Accepted: 13 October 2017

Published online: 20 October 2017

\section{References}

1. Gautam RK, Dixit PK, Mittal S. Herbal sources of antidepressant potential: a review. Int J Pharm Sci Rev Res. 2013;18(Suppl 1):86-91.

2. Shivashankara KS, Acharya SN. Bioavailability of dietary polyphenols and the cardiovascular diseases. Open Nutraceuticals J. 2010;3:227-41.

3. Stowe DF, Camara AKS. Mitochondrial reactive oxygen species production in excitable cells: modulators of mitochondrial and cell function. A review. Antioxid Redox Signal. 2009;11(Suppl 6):1373-414.

4. Szeto HH. Cell-permeable, mitochondrial-targeted, peptide antioxidants. AAPS J. 2006:8:32.

5. Rastogi RP, Singh SP, Häder D, Sinha RP. Detection of reactive oxygen species (ROS) by the oxidant-sensing probe 2',7'-dichlorodihydrofluorescein diacetate in the cyanobacterium Anabaena Variabilis PCC 7937. Biochem Biophys Res Commun. 2010;397(Suppl 3):603-7.

6. Działo M, Mierziak J, Korzun U, Preisner M, Szopa J, Kulma A. The potential of plant phenolics in prevention and therapy of skin disorders. Int J Mol Sci. 2016. 2016;17:160

7. Jothy SL, Zuraini SL, Sasidharan S. Phytochemicals screening, DPPH free radical scavenging and xanthine oxidase inhibitiory activities of Cassia Fistula seeds extract. J Med Plants Res. 2011;5:1941-7.

8. Hamid AA, Aiyelaagbe OO, Usman LA, Ameen OM, Lawal A. Antioxidants: its medicinal and pharmacological applications. Afr J Pure Appl Chem. 2010;4(8):142-51.

9. Lü JM, Lin PH, Yao Q, Chen C. Chemical and molecular mechanisms of antioxidants: experimental approaches and model systems. J Cell Mol Med. 2010;14(Suppl 4):840-60.

10. Komolafe K, Olaleye MT, Fasan TI, Elekofehinti OO, Saliu JA, Akindahunsi AA. Lipid-lowering effect of Parkia biglobosa leaf saponins in triton-X 1339induced hyperlipidemic rats. RJPBCS. 2013;4(Suppl 1):576-85.

11. Komolafe K, Olaleye TM, Seeger RL, Carvalho FB, Boligon AA, Athayde ML, Klimaczewski CV, Akindahunsi AA, Rocha JBT. Parkia biglobosa improves mitochondrial functioning and protects against neurotoxic agents in rat brain hippocampal slices. BioMed Res Intern 2014; doi:10.1155/2014/326290.

12. Olaleye TM, Komolafe $K$, Akindahunsi AA. Effect of methanolic leaf extract of Parkia biglobosa on some biochemical indices and hemodynamic parameters in rats. J Chem Pharm Res. 2013;5(Suppl 1):213-20.

13. Re R, Pellegrini N, Proteggente A, Pannala A, Yang M, Rice-Evans M. Antioxidant activity applying an improved ABTS radical cation decolorization assay. Free Rad Biol Med. 1999;26(Suppl 9-10):1231-7.

14. Batool F, Sabir SM, Rocha JBT, Shah AH, Saify ZS, Ahmed SD. Evaluation of antioxidant and free radical scavenging activities of fruit extract from Zanthoxylum alatum: a commonly used spice from Pakistan. Pak J Bot. 2010;42(Suppl 6):4299-311.

15. Oyaizu M. Studies on products of browning reactions: antioxidant activities of products of browning reaction prepared from glucose amine. Jpn J Nutr. 1986:44:307-15.

16. Puntel RL, Nogueira CW, Rocha JBT. N-methyl-D-aspartate receptors are involved in the quinolinic acid, but not in the malonate pro-oxidative activity in vitro. Neurochem Res. 2005;30(Suppl 3):417-24.

17. Sudati JH, Fachinetto R, Pereira RP, Boligon AA, Athayde ML, Soares FA, Barbosa NBV, Rocha JBT. In vitro antioxidant activity of Valeriana officinalis against different neurotoxic agents. Neurochem Res. 2009;34:1372-9.

18. Cushman DW, Cheung HS. Spectrophotometric assay and properties of the angiotensin-converting enzyme of rabbit lung. Biochem Pharmacol. 1971;20:1637-48.

19. Komolafe K, Olaleye TM, Omotuyi Ol, Boligon AA, Athayde ML, Akindahunsi AA, Rocha JBT. In vitro antioxidant activity and effect of Parkia biglobosa bark extract on mitochondrial redox status. J Acupunct Meridian Stud. 2014;7(4):202-10.

20. Lowry OH, Rosebrough NJ, Farr AL, Randall RJ. Protein measurement with the Folin phenol reagent. J Biol Chem. 1951;193(1):265-75. 
21. Hansson MJ, Månsson R, Morota S, Uchino H, Kallur T, Sumi T, Ishii N, Shimazu M, Keep MF, Jegorov A, Elmér E. Calcium-induced generation of reactive oxygen species in brain mitochondria is mediated by permeability transition. Free Radic Biol Med. 2008:45:284-94.

22. Pandey KB, Rizvi SI. Plant polyphenols as dietary antioxidants in human health and disease. Oxidative Med Cell Longev. 2009;2(5):270-8.

23. Pereira RP, Fachinetto R, Prestes AS, Puntel RS. Santos da Silava GN, Heinzmann BM et al. antioxidant effects of different extracts from Melissa officinalis, Matricaria recutita and Cymbopogon citrates. Neurochem Res. 2009;34(5):973-83.

24. Hazra B, Biswas S, Mandal N. Antioxidant and free radical scavenging activity of Spondias pinnata. BMC Complement Altern Med. 2008;8:63.

25. Ak T, Gulcin I. Antioxidant and radical scavenging properties of curcumin. Chem Biol Interact. 2008;174(1):27-37.

26. Ebrahimzadeh MA, Pourmorad F, Bekhradnia AR. Iron chelating activity, phenol and flavonoid content of some medicinal plants from Iran. Afr J Biotechnol. 2008;7(Suppl 18):3188-92.

27. Miller MR, Megson IL. Recent developments in nitric oxide donor drugs. Br J Pharmacol. 2007;151:305-21.

28. Berg RMG, Møller K, Bailey DM. Neuro-oxidative-nitrosative stress in sepsis. J Cereb Blood Flow Metab. 2011;31:1532-44.

29. Shukor NA, Camp JV, Gonzales GB, Staljanssens D, Struijs K, Zoitti MJ, Raes K, Smagghe $G$. Angiotensin-converting enzyme inhibitory effects by plant phenolic compounds: a study of structure activity relationships. J Agric Food Chem. 2013;61(Suppl 48):11832-9.

30. Kwon EK, Lee DY, Lee H, Kim DO, Baek NI, Kim YE, Kim HY. Flavonoids from the buds of Rosa damascene inhibit the activity of 3-hydroxy-3methylglutaryl-coenzyme a reductase and angiotensin I-converting enzyme. J Agric Food Chem. 2010;58:882-6.

31. Cillero-Pastor B, Martin MA, Arenas J, López-Armada MJ, Blanco FJ. Effect of nitric oxide on mitochondrial activity of human synovial cells. BMC Musculoskelet Disord. 2011;12:42.

32. Maneiro E, López-Armada MJ, de Andres MC, Caramés B, Martín MA, Bonilla $A$, et al. Effect of nitric oxide on mitochondrial respiratory activity of human articular chondrocytes. Ann Rheum Dis. 2005;64(Suppl 3):388-95.

33. Valko M, Leibfritz D, Moncol J, Cronin MTD, Mazura M, Telser J. Free radicals and antioxidants in normal physiological functions and human disease. A review. Int J Biochem Cell Biol. 2007;39:44-84.

34. Dai Y, Weinreb RN, Kim KY, Nguyen D, Park S, Sun X, Lindsey JD, Ellisman $\mathrm{MH}$, Ju WK. Inducible nitric oxide synthase-mediated alteration of mitochondrial opa1 expression in ocular hypertensive rats. Invest Ophthalmol Vis Sci. 2011;52:2468-76.

35. Roos DH, Puntel RL, Farina M, Aschner M, Bohrer D, Rocha JBT, Barbosa NBV. Modulation of methylmercury uptake by methionine: prevention of mitochondrial dysfunction in rat liver slices by a mimicry mechanism. Toxicol Appl Pharm. 2011;252:28-35.

36. Görlach A, Bertram K, Hudecova S, Krizanova O. Calcium and ROS: a mutual interplay. Redox Biol. 2015;6:260-71.

37. Perron NR, Brumaghim JL. A review of the antioxidant mechanisms of polyphenol compounds related to iron binding. Cell Biochem Biophys, 2009:53:75-100.

38. Wang X, Gong J, Liu X, Zhan R, Kong R, Zhao Y, Wan D, Leng X, Chen M, Qian L. Expression of uncoupling protein 3 in mitochondria protects against stress-induced myocardial injury: a proteomic study. Cell Stress Chaperon. 2010;15:771-9.

39. Adam-Vizi V, Starkov AA. Calcium and mitochondrial reactive oxygen species generation: how to read the facts. J Alzheimers Dis. 2010;20(Suppl 2):413-26.

40. Onyango IG, Dennis J, Khan SM. Mitochondrial dysfunction in Alzheimer's disease and the rationale for bioenergetics based therapies. Aging Dis. 2016:7(2):201-14

41. Garcia-Martinez EM, Sanz-Blasco S, Karachitos A, Bandez MJ, FernandezGomez FJ, Perez-Alvarez S, et al. Mitochondria and calcium flux as targets of neuroprotection caused by minocycline in cerebellar granule cells. Biochem Pharmacol. 2010;79(Suppl 2):239-50.

42. Wu J, Cui Y, Yang Y, Jung S, Hyun JW, Maeng Y, et al. Mild mitochondrial depolarization is involved in a neuroprotective mechanism of Citrus sunki peel extract. Phytother Res. 2012; doi:10.1002/ptr.4745.

\section{Submit your manuscript to a SpringerOpen ${ }^{\circ}$ journal and benefit from:}

- Convenient online submission

- Rigorous peer review

- Open access: articles freely available online

- High visibility within the field

- Retaining the copyright to your article

Submit your next manuscript at $\boldsymbol{\nabla}$ springeropen.com 